\title{
Modeling and Mapping Forest Floor Distributions of Common Bryophytes Using a LiDAR-Derived Depth-to-Water Index
}

\author{
Monique Goguen, Paul A. Arp \\ Forest Watershed Research Centre, Faculty of Forestry and Environmental Management, University of New Brunswick, \\ Fredericton, New Brunswick, Canada \\ Email: arp2@unb.ca
}

How to cite this paper: Goguen, M. and Arp, P.A. (2017) Modeling and Mapping Forest Floor Distributions of Common Bryophytes Using a LiDAR-Derived Depthto-Water Index. American Journal of Plant Sciences, 8, 867-890.

https://doi.org/10.4236/ajps.2017.84059

Received: January 14, 2017

Accepted: March 28, 2017

Published: March 31, 2017

Copyright $\odot 2017$ by authors and Scientific Research Publishing Inc. This work is licensed under the Creative Commons Attribution International License (CC BY 4.0).

http://creativecommons.org/licenses/by/4.0/

\begin{abstract}
This article describes how the cartographic depth-to-water (DTW) index in combination with other variables can be used to quantify, model and map the distribution of common forest floor bryophytes, at $1 \mathrm{~m}$ resolution. This was done by way of a case study, using 12 terrain and climate representative locations across New Brunswick, Canada. The presence/absence by moss species was determined at each location along upland-to-wetland transects within $>10-\mathrm{m}$ spaced $1-\mathrm{m}^{2}$ forest floor plots. It was found that Bazzania trilobata, Dicranum polysetum, Polytrichum commune, Hylocomium splendens, and Pleurozium schreberi had greater probabilities of occurrence in welldrained forested areas, whereas Sphagnum fuscum and Sphagnum girgensohnii dominated in low-lying wet areas. The presence/absence of each species was quantified by way of logistic regression analyses, using DTW, slope, canopy closure, forest litter depth, ecosite type (8 classes), nutrient regime (4 classes, poor to rich); vegetation type (deciduous, coniferous, mixed, and shrubs), and macro- and micro-topography (upland, wetland; mounds, pits) as predictor variables. Among these, $\log _{10}$ DTW and forest litter depth were the most consistent predictor variables, followed by mound versus pit. For the mapping purpose, only $\log _{10}$ DTW and already mapped classifications for upland versus wetland and vegetation type were used to predict the probability of occurrences for the most frequent moss species, namely, D. polysetum, $P$. schreberi and Sphagnum spp. The overall accuracy for doing this ranged from $67 \%$ to $83 \%$, with false positives and negatives amounting to $18 \%$ to $42 \%$. The overall classification accuracy exceeded the probability by chance alone at $76.8 \%$, with the significance level reached at $75.3 \%$. The average level of probability by chance alone was $60.3 \%$.
\end{abstract}




\section{Keywords}

Bryophytes, Wet Areas, Macro- and Micro-Topography, Forest Floor, Forest Litter, Mound And Pit, Canopy Closure, Digital Elevation Modeling, Logistic Regression

\section{Introduction}

Data available for mapping natural vegetation distributions at high-resolution have become increasingly accessible and important for environmental research, monitoring, and impact assessments [1]. Predictive vegetation mapping of bryophytes, however, is still largely unexplored [2]. Where bryophyte-environment relationships have been studied, the focus has either been placed on the micro-scale (e.g., [3] [4] [5]) or on large regional to global scales (e.g., [6] [7] [8] [9] [10]). This research differs in perspective by looking at bryophyte distributions along the forest floor at the landscape scale, at $1 \mathrm{~m}$ resolution. Earlier landscape studies were typically done at coarser scales (e.g., [2] [3] [11]). The objectives of this article are:

1. To determine how the occurrences of specific moss species vary by forest floor and location conditions across select New Brunswick locations, based on $1-\mathrm{m}^{2}$ plot surveys along upland/wetland transects, and by variations in soil wetness, slope, canopy closure, and litter depth. Other variables refer to aspect, ecosite classes, vegetation type (poor to rich), upland versus lowland, microsite topography (mound, flat, pit), soil type (organic, mineral), ecoregion and sampling location.

2. To transform the resulting presence/absence patterns into species-specific occurrence probability models by way of logistic regression analysis.

3. To validate and to apply the models so obtained for landscape-wide mossoccurrence probability mapping.

The focus is on modelling and mapping moss distributions on the forest floor as opposed to other moss-preferred substrates such as fallen logs, rocks and barren ground, because forest floor conditions impose more exacting constraints on the presence or absence of bryophyte species [12]. For example, species with specific soil moisture regime preferences would primarily occur where water would remain at or near the surface throughout the growing seasons. In contrast, mesic/xeric species would-by definition-occur on better-drained uplands where the water table below the forest floor is further below the surface. In addition, increasing canopy closure would negatively affect the presence of mosses and moss carpets on the forest floor through (i) increasing moisture loss under open conditions, (ii) insufficient light availability under dark conditions, and (iii) increasing leaf-litter fall.

There are 381 bryophyte species in the maritime provinces (New Brunswick, Nova Scotia, and Prince Edward Island) [13], with at least 322 species in New Brunswick alone [14]. For this study, thirteen species were selected by likely 
commonness across the province, and by their reported moisture regime preferences. None of the species so selected are rare, endangered, or endemic. For example, feather mosses such as Hylocomium splendens, Pleurozium schreberi, and Ptilium crista-castrensis are common forest floor species on shaded and well drained areas [13] [15] [16]. These species are also often found in association with Dicranum spp. [17]. Sphagnum species such as $S$. wulfianum and $S$. girgensohnii build extensive carpets across wetlands and wet microsites [18].

The means to determine how changes in soil moisture regimes would affect upland-to-wetland distributions of individual moss species was enabled through the increasing availability of high-resolution bare-earth digital elevation models (DEMs). Through DEM raster derivations involving slope, aspect, flow direction, flow accumulation, and flow network, two important soil moisture indicators emerged: (i) the terrain wetness index (TWI), and (ii) the cartographic depth-to-water index (DTW). The reported utilities of these indices favor DTW in terms of achieving greater conformance with field-measured variables such as soil drainage regime, soil type, various soil physical and chemical properties, soil trafficability, and vegetation type by soil moisture regime preference [19] [20] [21]. The difference between DTW and TWI pertains to the greater dependence of TWI on DEM resolution and smoothing [20]. Therefore, this article focuses on DTW for the purpose of forest floor bryophyte mapping at 1-m resolution.

\section{Methods}

Plot-based surveys were conducted across New Brunswick by selecting 12 areas for which 1-m resolution LiDAR-derived digital elevation models have become available (Figure 1; LiDAR: Light Detection and Ranging). These areas from ridge tops through valleys and wetlands, and were reasonably representative of the physiographic and climatic conditions across New Brunswick (Table 1). Additional criteria for location selection involved (i) accessibility, (ii) ownership (New Brunswick crownlands), (iii) low to no levels of industrial/residential developments, (iv) minimal human influence (e.g., not affected by dissecting roads), and (v) overall representation of New Brunswick ecoregions.

Sample plots were centered on forest floor and walkable wetland surfaces locations, as opposed to potential plots on large boulders and logs. Species composition and relative abundance of all ground flora were recorded for $9801-\mathrm{m}^{2}$ quadrats. Mosses were identified using hand lenses, and samples were brought back to the lab for identification under a microscope as needed. Relative abundance was recorded for each species based on percent area coverage when viewed from above [22]. Plot observations were done twice through independent viewing. Each plot was photographed for further validation purposes. The sampling locations were assigned to two groups: eleven for modelling moss presence and absence of specific moss species across New Brunswick (950 quadrats), and one for model validation (301 quadrats; University of New Brunswick Forest, Fredericton). 


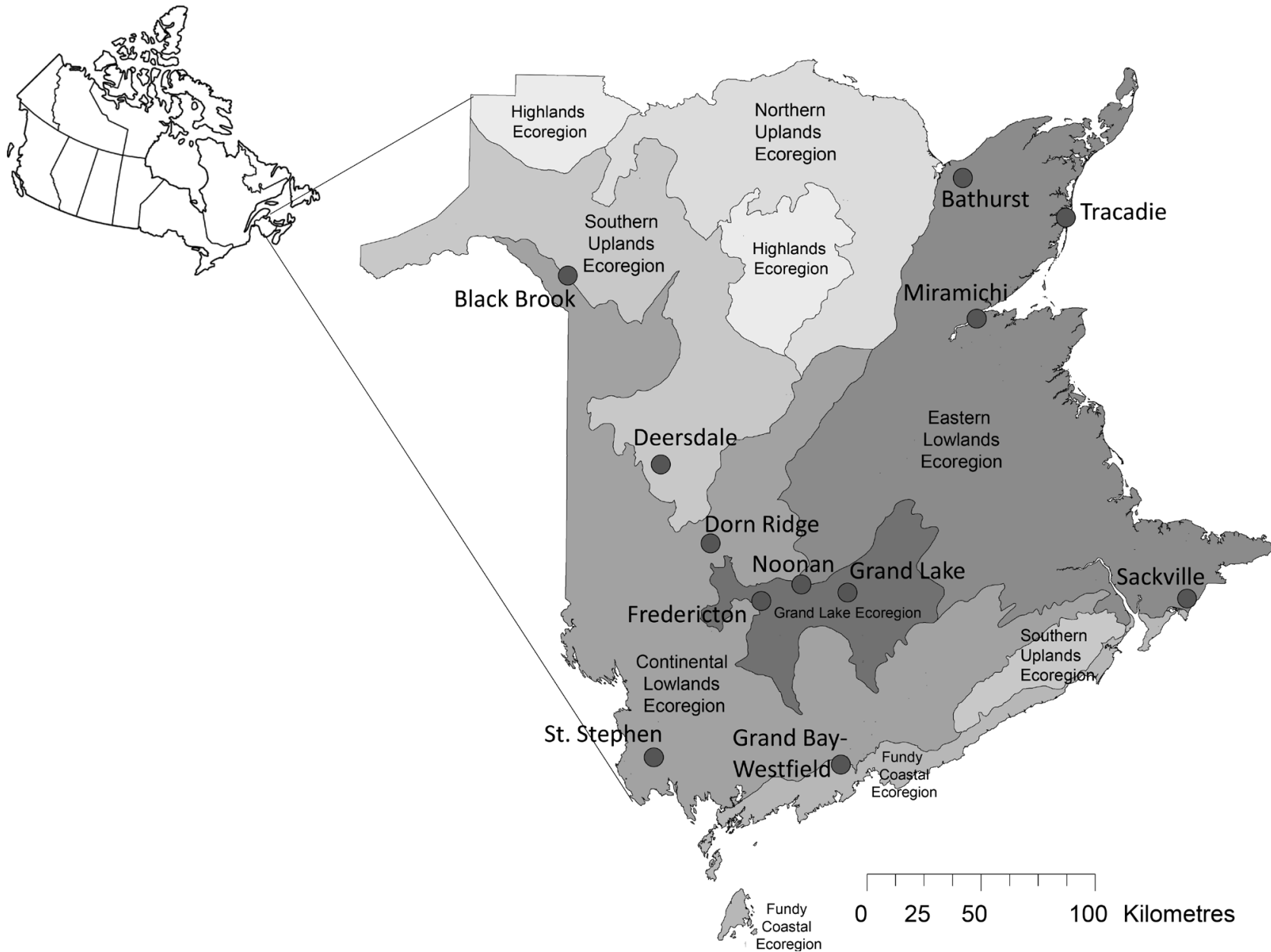

Figure 1. Moss survey locations across New Brunswick.

Table 1. Surveyed areas, by ecoregion, location, number of plots (n), climate conditions (1981-2010 Climate Normals, Environment Canada), and elevation.

\begin{tabular}{|c|c|c|c|c|c|c|c|c|c|}
\hline Ecoregion & Site & $\mathbf{n}$ & $\begin{array}{c}\text { Mean } \\
\text { Annual } \\
\text { Temperature } \\
\left({ }^{\circ} \mathrm{C}\right)\end{array}$ & $\begin{array}{l}\text { Precipitation } \\
\quad(\mathrm{mm})\end{array}$ & $\begin{array}{c}\text { Degree } \\
\text { Days } \\
\text { Above } 5^{\circ} \mathrm{C}\end{array}$ & $\begin{array}{c}\text { Elevation } \\
\text { Range } \\
\text { (MASL) }\end{array}$ & $\begin{array}{c}\text { Area } \\
\text { Surveyed } \\
\text { (ha) }\end{array}$ & Longitude & Latitude \\
\hline \multirow{4}{*}{$\begin{array}{l}\text { Eastern } \\
\text { Lowlands }\end{array}$} & Bathurst & 80 & 4.8 & 1110.1 & 1690.8 & $20-98$ & 103.1 & $65^{\circ} 30^{\prime} 28.352^{\prime \prime} \mathrm{W}$ & $47^{\circ} 36^{\prime} 18.942^{\prime \prime} \mathrm{N}$ \\
\hline & Tracadie & 70 & 4.8 & 1077.2 & 1658.5 & $0-20$ & 92.3 & $64^{\circ} 54^{\prime} 16.418^{\prime \prime} \mathrm{W}$ & $47^{\circ} 25^{\prime} 59.695^{\prime \prime} \mathrm{N}$ \\
\hline & Miramichi & 90 & 4.9 & 1072.4 & 1718.5 & $0-98$ & 57.5 & $65^{\circ} 26^{\prime} 0.137^{\prime \prime} \mathrm{W}$ & $47^{\circ} 2^{\prime} 34.122^{\prime \prime N}$ \\
\hline & Sackville & 70 & 5.6 & 1146.5 & 1629.9 & -59 & 122.2 & $64^{\circ} 15^{\prime} 41.994^{\prime \prime W}$ & $45^{\circ} 55^{\prime} 24.145^{\prime \prime} \mathrm{N}$ \\
\hline \multirow{3}{*}{$\begin{array}{l}\text { Northwestern } \\
\text { Uplands }\end{array}$} & Blackbrook & 90 & 3.5 & 1104.1 & 1532.6 & $212-325$ & 230.4 & $67^{\circ} 47^{\prime} 56.469^{\prime \prime} \mathrm{W}$ & $47^{\circ} 12^{\prime} 40.761^{\prime \prime N}$ \\
\hline & Deersdale & 90 & 3.7 & 1159.7 & 1544.3 & $360-492$ & 155.3 & $67^{\circ} 14^{\prime} 39.079^{\prime \prime} \mathrm{W}$ & $46^{\circ} 28^{\prime} 19.719^{\prime \prime} \mathrm{N}$ \\
\hline & Dorn Ridge & 80 & 4.3 & 1088.9 & 1608.7 & $199-305$ & 78.8 & $66^{\circ} 57^{\prime} 27.465^{\prime \prime} \mathrm{W}$ & $46^{\circ} 9^{\prime} 46.043^{\prime \prime} \mathrm{N}$ \\
\hline \multirow[t]{3}{*}{$\begin{array}{c}\text { Valley } \\
\text { Lowlands }\end{array}$} & Grand Bay-Westfield & 160 & 5.2 & 1295.5 & 1542.4 & $44-118$ & 52.9 & $66^{\circ} 13^{\prime} 45.396^{\prime \prime} \mathrm{W}$ & $45^{\circ} 17^{\prime} 24.246^{\prime \prime N}$ \\
\hline & St. Stephen & 90 & 5.2 & 1429.7 & 1388.4 & $85-162$ & 232.1 & $67^{\circ} 15^{\prime} 55.725^{\prime \prime} \mathrm{W}$ & $45^{\circ} 19^{\prime} 21.677^{\prime \prime} \mathrm{N}$ \\
\hline & Grand Lake & 80 & 5.2 & 1175.8 & 1738.5 & -60 & 93.3 & $66^{\circ} 11^{\prime} 2.744^{\prime \prime} \mathrm{W}$ & $45^{\circ} 58^{\prime} 4.157^{\prime \prime} \mathrm{N}$ \\
\hline \multirow[t]{2}{*}{$\begin{array}{l}\text { Grand Lake } \\
\text { Lowlands }\end{array}$} & Noonan & 80 & 5.2 & 1175.8 & 1738.5 & $13-150$ & 98.4 & $66^{\circ} 26^{\prime} 23.165^{\prime \prime} \mathrm{W}$ & $46^{\circ} 0^{\prime} 18.091 " \mathrm{~N}$ \\
\hline & Fredericton & 325 & 5.6 & 1077.7 & 1803.5 & $1-186$ & 1400 & $66^{\circ} 40^{\prime} 42.408^{\prime \prime} \mathrm{W}$ & $45^{\circ} 55^{\prime} 52.062^{\prime \prime} \mathrm{N}$ \\
\hline
\end{tabular}


Forest floor sampling plots were spaced $>10 \mathrm{~m}$ apart at each location from upland to wetlands [23], and were representatively chosen across 8 DTW classes ranging from very wet $(\mathrm{DTW}<0.1 \mathrm{~m})$ to dry $(\mathrm{DTW}>12 \mathrm{~m})$. Each plot determination involved specifying:

- Plot location by longitude and latitude.

- Moss species, by presence and abundance (all species); species were identified on-site using hand lenses, followed by microscopic indoor confirmation using a microscope, and Ireland and Hanes (1982) as authoritative species identification guide.

- Leaf litter layer (L) depths.

- Micro-topography classes (mound versus pit) [24] [25].

- Canopy closure.

- Tree species composition by vegetation type (VT [26]), with VT ranging from 1 (predominantly ericaceous species associated with poor soil conditions) to 4 (tolerant hardwood tree species associated with rich site conditions).

- Ecosite category (eight classes: bog, fen, freshwater marsh, shrub wetland, forested wetland, ecotone, or riparian zone) [26].

- Wetland versus upslope location, with 1 denoting wetland, 0 otherwise.

These plot-specific assignments were further checked by cross-referencing with (i) GIS data layers pertaining to forest inventory and wetland cover and type, and (ii) aerial photographs [27]. LiDAR-derived 1-m resolution digital elevation models (DEMs) were used to generate the cartographic depth-to-water index (DTW) for each site (Figure 2). This index determines the difference in elevation between the ground surface and the nearest open-water features, such as flow channels and water pools. As such, it also emulates the gradation in soil drainage from very poor, poor, imperfect, moderate, well and excessively well [20] [28]. Table 2 provides a summary of all transect and plot determined numerical and categorical variables, by map-versus plot-based categories. The map-based variables were used for province-wide moss distribution mapping, whereas the plot-determined variables were intended to reveal finer resolution and therefore not-yet projectable moss-distribution differences.

All the data so assembled were entered into a single spreadsheet, which each column identified by plot, location, species and variable, and each row referring to plot-specific observations. Species absence/presence was also noted through binary coding ( 1 for present, and 0 for absent). The data so compiled were then used for (i) generating the probability response curves (Figure 3 ) for each species, (ii) multivariate logistic regression analyses and classification, and (iii) model-based presence-absence probability projections.

The probability response curves were calculated with the statistical programming environment R 3.1.2 [29], using the eHOF package v. 1.5.7 [30], with all model parameters (a, b, c, d) obtained through non-linear maximum likelihood estimation procedures [31]). Selection of the most adequate model type was done using the Akaike Information Criterion (AIC [32] [33]). For this analysis, 


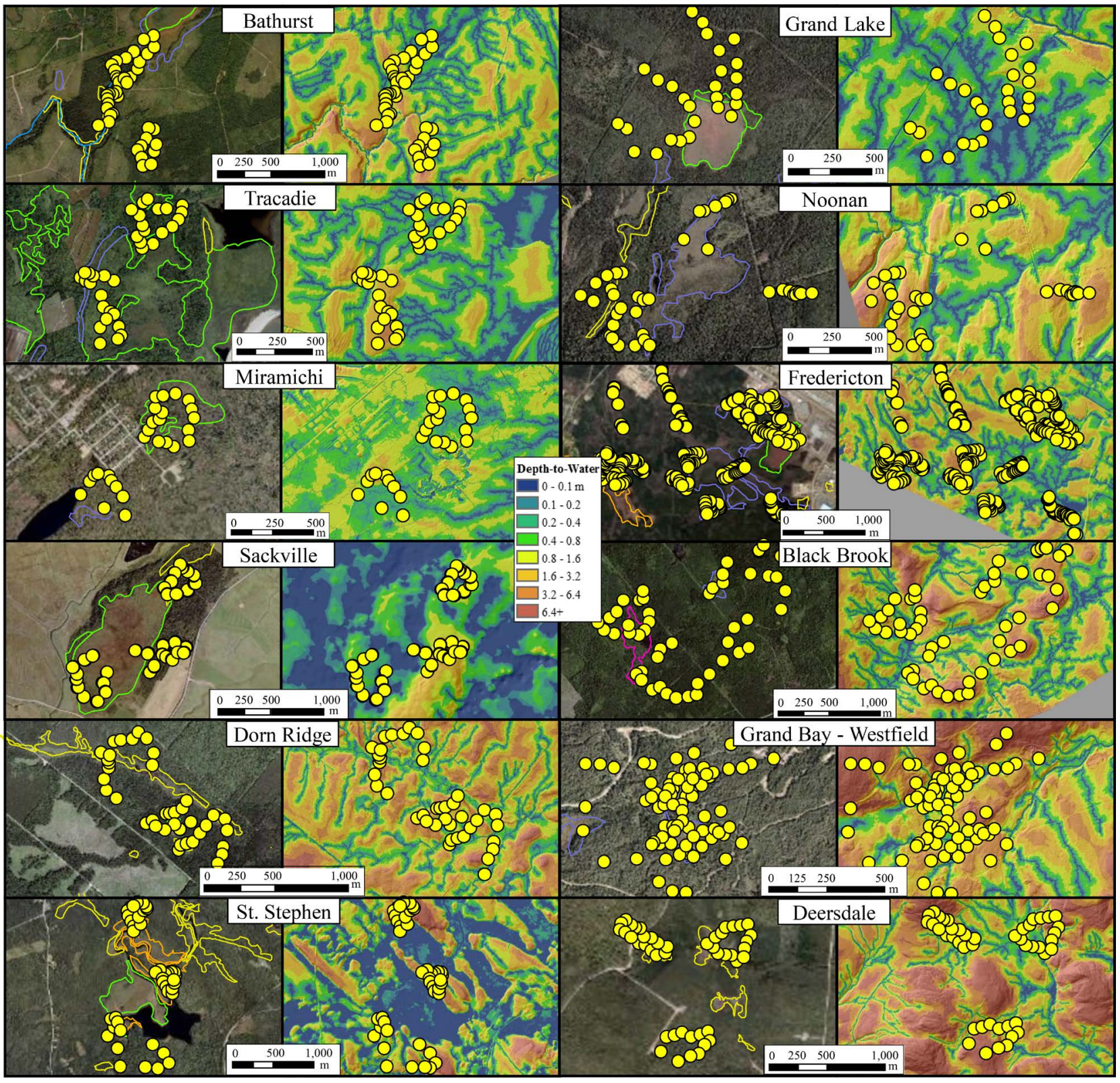

Figure 2. Panels show side-by-side surface image and depth-to-water map for each of the 12 survey locations across New Brunswick, also showing wetland outlines and the individual upland-to-wetland plot locations.

Table 2. Variables associated with each moss sampling plot.

\begin{tabular}{|c|c|c|c|c|}
\hline & Variable & & Description & Units \\
\hline \multirow{6}{*}{ Map-based } & Numerical & DTW & $\log _{10}(\mathrm{DTW})$ & $\log _{10}(\mathrm{~m})$ \\
\hline & & Slope & Slope ( $20 \mathrm{~m}$ focal average) & $\%$ \\
\hline & & Canopy Closure & From forest inventory & $\%$ classes \\
\hline & Categorical & Aspect & Aspect ( $20 \mathrm{~m}$ focal average) & 4 Classes \\
\hline & & Ecosite & $\begin{array}{l}\text { Bog, Fen, Marsh, Forest wetland, } \\
\text { Shrub wetland, Riparian zone, } \\
\text { Upland }\end{array}$ & 8 Classes \\
\hline & & Forest Type & Forest Type (SW, HW, MX, Other) & 4 Classes \\
\hline \multirow{4}{*}{ Plot-based } & Numerical & L-Layer & Depth of litter layer & $\mathrm{cm}$ \\
\hline & & VT & Vegetation Type (1-Poor to 4-Rich) & 4 Classes \\
\hline & Categorical & Microsite & Mound or pit & 2 Classes \\
\hline & & Soil Type & Organic vs. mineral soil & 2 Classes \\
\hline
\end{tabular}



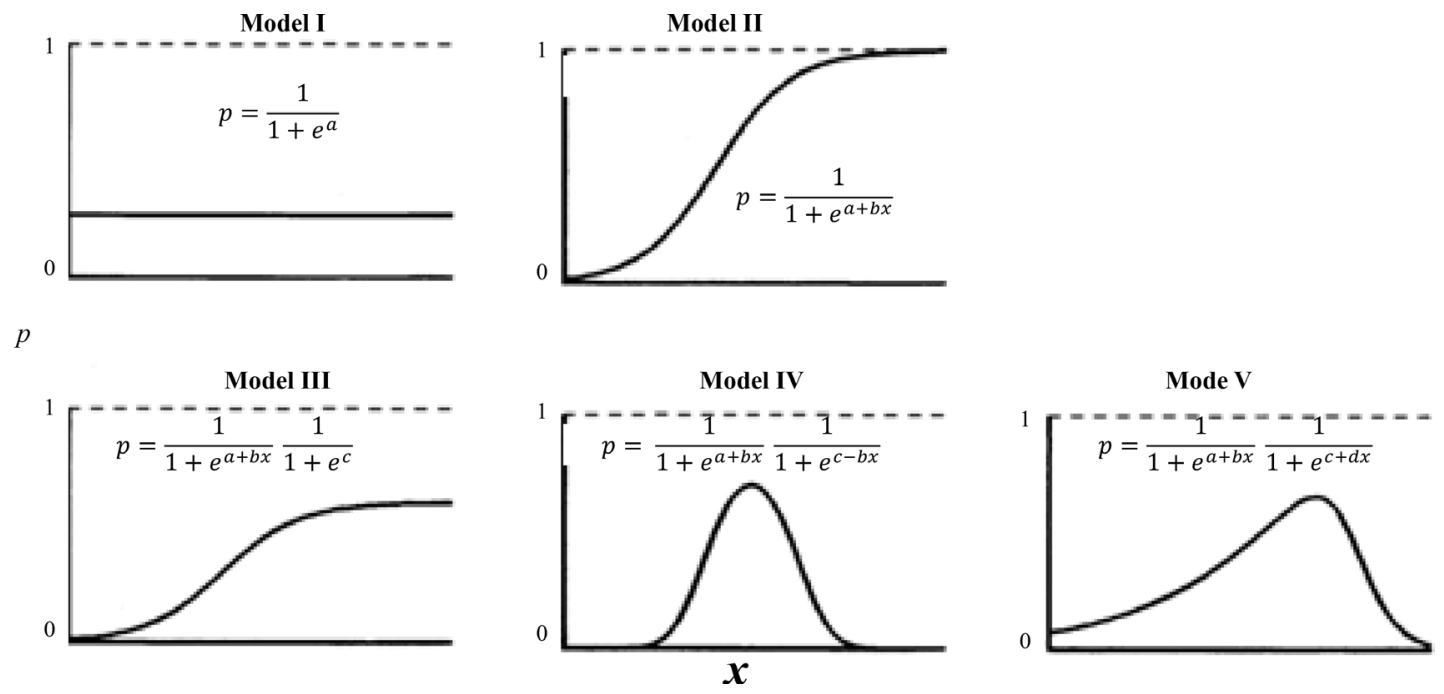

Figure 3. Theoretical species absence/presence probability response models, ranked by increasing complexity: (I) no response, (II) sigmoidal, (III) sigmoidal with plateau, (IV) unimodal symmetric, and (V) unimodal skewed; direction of $\mathrm{x}$ is reversible (from [37]).

species with less than 50 observations $(\mathrm{n}<50)$ needed to be omitted [34] [35] [36]. This narrowed the analysis to seven species: Bazzania trilobata (BT), Dicranum polysetum (DP), Hylocomium splendens (HS), Polytrichum commune $(P C)$, Pleurozium schreberi (PS), Sphagnum fuscum $(S F)$, and Sphagnum girgensohnii $(S G)$.

The binary presence/absence were also evaluated for each moss species in relation to (i) all the variables in Table 2 and (ii) the best-fitted HOF response models. This was done using Equation (1) and the logistic multivariate regression process (SPSS Statistics for Windows, Version 2.2.0; IBM Corp., 2013) as follows:

$$
\log \left(\frac{p}{1-p}\right)=\alpha+\beta_{1} x_{1}+\cdots+\beta_{k} x_{k}+\text { residuals }
$$

with $p$ as the species-specific occurrence probability, $\alpha$ and $\beta_{i}$ as parameters, and $x_{i}(i=1,2, \ldots k)$ as explanatory regression variables [38] [39].

The presence/absence data of species with $\mathrm{n}>50$ was analysed by way of logistic regression, using all the variables in Table 2 as potential moss presence/absence predictor variables. The least significant predictor variables with $a$ $<0.05$ (Wald test [40]) were eliminated, one step at a time. Within a set of closely correlated predictor variables, only the more significant variables were retained. The model coefficients so obtained were checked for possible collinearity using the variance inflation factor measure (VIF [41]). Akaike's Information Criterion (AIC) scores were used to select among the best-fitted models [32], with the goodness of fit evaluated using the likelihood ratio test and two pseudo $R^{2}$ measures: Cox and Snell $R^{2}$ and Nagelkerke $R^{2}$ [32] [39] [42].

\subsection{Model-Based Classification Including Validation.}

Model Performance Receiver Operating Characteristic (ROC, SPSS) curves 
served as a measure of the classification accuracy of logistic regression models for the most common moss species, i.e., $D P, P S$, and $S G$. The area under the resulting ROC curves (AUC) determines the discriminatory ability of the model, and varies from 0.5 (no better than chance) to 1.0 (perfect discrimination [43]). Models with AUC values $>0.7$ are considered to have high discriminatory power [38]. The classification accuracy was further evaluated using the proportional-by-chance accuracy rate, which is calculated by summing the squared proportion that each group (present/absent as observed) of the total sample across all sampling locations [44]. For model development and validation purpose, sampling locations were assigned to two groups: eleven for model development (980 quadrats), and one for model validation (325 quadrats; University of New Brunswick Forest, Fredericton). The logistic regression models generated from the former served to predict the plot-based moss occurrences for the latter. The resulting classification accuracy was evaluated as described above.

\subsection{Model Projections and Mapping}

The best-fitted regression models were used to map the probability of $D P, P S$, and $S G$ presence across the landscape at each of the 12 sampling locations using ArcGIS mapping procedures [45].

\section{Results}

Occurrence frequencies varied widely by moss species, from common to uncommon (Table 3). Climacium dendroides, Ptilium crista-castrensis, Rhytidiadelphus triquetrus, Sphagnum squarrosum, Aulacomnium palustre and Sphagnum wulfianum were locally abundant in terms of percent cover at only a few locations. In contrast, $P S$ and $S G$ were most common, appearing respectively in 328 and 301 of the 980 plots. $D P$ was next, with 233 plot observations. $S F, H S$, $B T$, and $P C$ occurred within 63 to 137 plots. The plots in Figure 4 show how the more abundant moss species were related plot-specific variations in DTW, canopy closure, slope and forest litter depth, with Sphagnum spp. occurring more frequently than the other species on wet, flat and open locations with little to no litter fall. The extent of percent moss cover per plot (i) by upland versus wetland and (ii) by mound versus pit locations on is also shown in Figure 4 .

The HOF modelled presence/absence response curves to the continuous variables $\log _{10}$ DTW, slope, \% canopy closure and forest litter depth followednon-linear trends (Figure 5), with $D P, H S, P C$ and $P S$ displaying unimodal bell-shaped responses (HOF models IV and V). In contrast, $S G$ and $S F$ decreased monotonically (HOF models II and III) from wet to dry, as to be expected [47] [48]. The resulting best-fitted model parameters, optima and niche values are listed in Table 4, with $\mathrm{R}^{2}$ values ranging from 0.16 to 0.99 . Only 5 of the 28 resulting models were not statistically significant with $\mathrm{P}>0.1$. Among these, $H S$ had the lowest $\mathrm{R}^{2}$ values in response to $\log _{10} \mathrm{DTW}$ and forest litter depth. After excluding the $H S$ response model to $\log _{10} \mathrm{DTW}$, the best-fitted $\mathrm{R}^{2}$ and $\mathrm{P}$ values followed this sequence: DTW > Litter depth $>$ Slope $>$ Canopy closure. 
Table 3. Soil moisture and nutrient preferences of the most common bryophyte species within the 11 sampling locations used for model development, including counts, frequency of occurrence, and mean percent cover per $1 \mathrm{~m}^{2}$ for a total of 980 sampling plots.

\begin{tabular}{|c|c|c|c|c|c|c|}
\hline Moss Species & Common Name & $\begin{array}{l}\text { Moisture } \\
\text { Regime }\end{array}$ & $\begin{array}{l}\text { Nutrient } \\
\text { Regime }\end{array}$ & $\begin{array}{c}\text { Count } \\
\text { (n) }\end{array}$ & Frequency \% & $\begin{array}{c}\text { Mean } \\
\text { Cover \% }\end{array}$ \\
\hline $\begin{array}{l}\text { Sphagnum } \\
\text { wulfianum }\end{array}$ & $\begin{array}{l}\text { Brittle-stemmed } \\
\text { sphagnum }\end{array}$ & wet & poor & 17 & 1.7 & 16.3 \\
\hline $\begin{array}{l}\text { Aulacomnium } \\
\text { palustre }\end{array}$ & Ribbed bog moss & wet/moist & medium & 18 & 1.8 & 2.6 \\
\hline $\begin{array}{l}\text { Climacium } \\
\text { dendroides }\end{array}$ & Tree moss & wet/moist & rich & 18 & 1.8 & 6.5 \\
\hline $\begin{array}{c}\text { Sphagnum } \\
\text { squarrosum }\end{array}$ & $\begin{array}{c}\text { Prickly } \\
\text { sphagnum }\end{array}$ & wet & poor & 24 & 2.4 & 16.4 \\
\hline $\begin{array}{c}\text { Rhytidiadelphus } \\
\text { triquetrus }\end{array}$ & Shaggy moss & moist/fresh & poor/medium/rich & 25 & 2.6 & 20.1 \\
\hline $\begin{array}{c}\text { Ptilium } \\
\text { crista-castrensis }\end{array}$ & Plume moss & moist/fresh/dry & poor & 35 & 3.6 & 3.5 \\
\hline $\begin{array}{l}\text { Sphagnum } \\
\text { fuscum }(S F)\end{array}$ & $\begin{array}{l}\text { Brown bog } \\
\text { sphagnum }\end{array}$ & wet & poor & 63 & 6.4 & 49.6 \\
\hline $\begin{array}{c}\text { Hylocomium } \\
\text { splendens }(H S)\end{array}$ & Stair-step moss & wet/moist/fresh & poor & 64 & 6.5 & 10 \\
\hline Bazzania trilobata $(B T)$ & Bazzania & moist/fresh & N/A & 76 & 7.8 & 6.6 \\
\hline $\begin{array}{c}\text { Polytrichum } \\
\text { commune }(P C)\end{array}$ & $\begin{array}{c}\text { Common } \\
\text { Haircap moss }\end{array}$ & wet/moist/fresh & poor/medium & 137 & 14 & 10.4 \\
\hline $\begin{array}{c}\text { Dicranum } \\
\text { polysetum }(D P)\end{array}$ & Wavy dicranum & wet/moist & poor/medium & 233 & 23.8 & 5.7 \\
\hline $\begin{array}{c}\text { Sphagnum } \\
\text { girgensohnii (SG) }\end{array}$ & $\begin{array}{l}\text { Common green } \\
\text { sphagnum }\end{array}$ & wet/moist & poor/medium & 301 & 30.7 & 47.7 \\
\hline $\begin{array}{c}\text { Pleurozium } \\
\text { schreberi }(P S)\end{array}$ & Schreber's moss & moist/fresh/dry & poor/medium & 328 & 33.5 & 21.8 \\
\hline
\end{tabular}

Sources: [13] [24] [46].
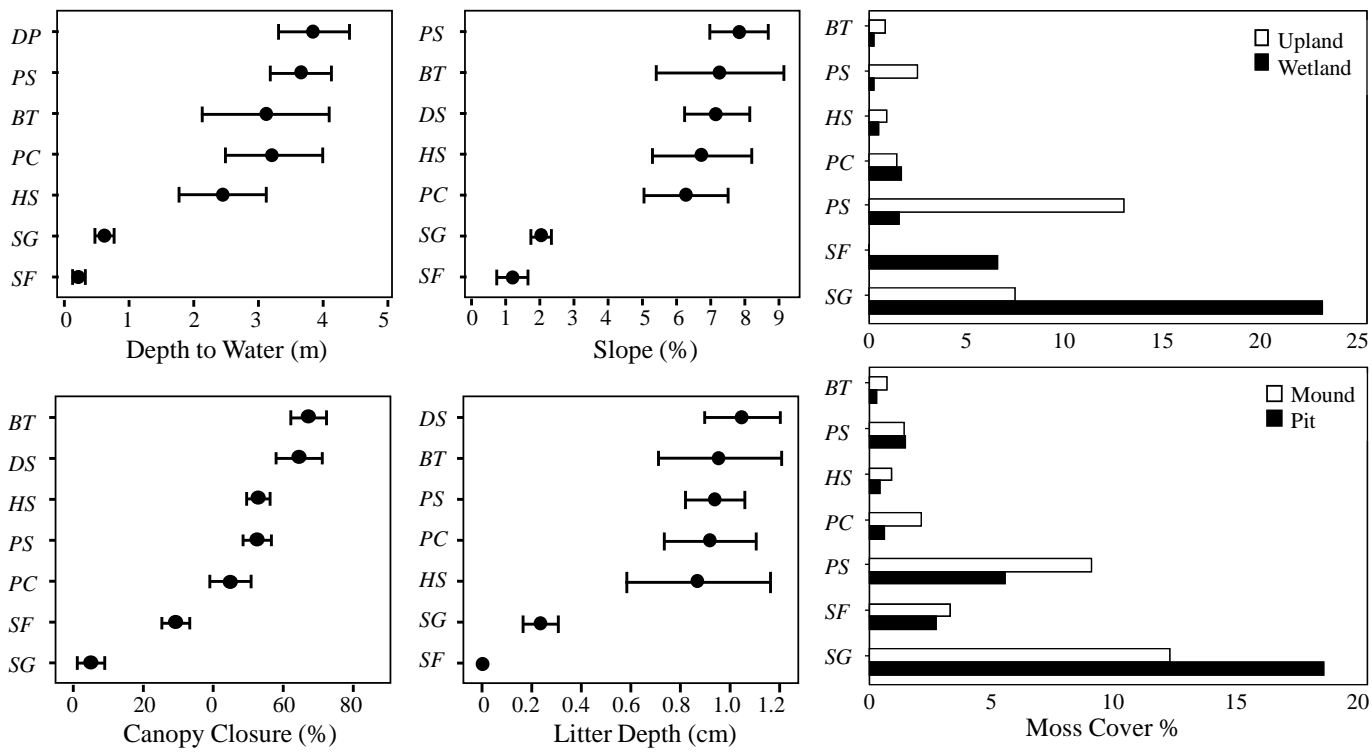

Figure 4. Mean values and their corresponding 95\% confidence intervals for depth-to-water (a), percent slope (b), percent canopy closure (c), and leaf litter depth (d) associated with the occurrences of 7 moss species across the 11 sampling locations used for model development. Also shown: bar diagrams for comparing mean percent moss cover per plot of the same 7 species by upland versus wetland (top right), and by mound versus pit (bottom right) locations. 

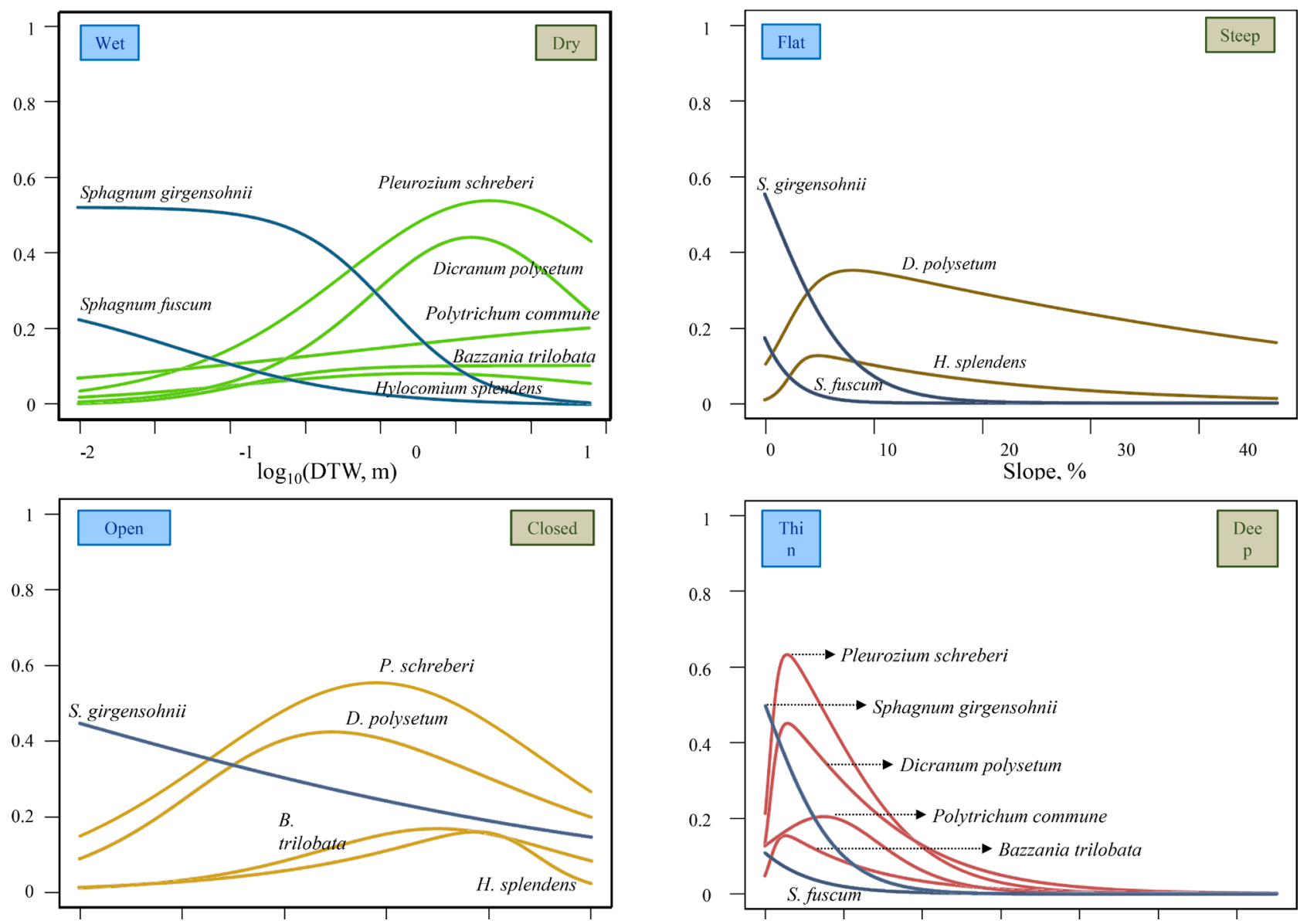

Figure 5. Best-fitted HOF presence probability response curves for the more frequent moss species of this study (n $>50$ ), by DTW, slope, canopy closure, and forest litter depth.

The best-fitted logistic regression results for the species with $n>50$ are compiled and summarized in Table 5 and Table 6. Of note are: (i) the consistently negative occurrence responses to (i) increasing litter depth, (ii) the positive versus negative effects of mound versus pit, upland versus wetland, and increasing versus decreasing $\log _{10} \mathrm{DTW}$, and (iii) the varying effect of canopy closure. In one case $(S G)$, slope (20 m focal mean) produced better results than $\log _{10} \mathrm{DTW}$. Dropping one or more of the variables in Table 4 in favour of other somewhat correlated variables (e.g., $\log _{10}$ DTW versus slope or wetland/upland location; canopy closure versus litter depth, SW or MX) increased the significance of some of those variables, but weakened the overall goodness of fit. SW or MX) increased the significance of some of these variables, but weakened the overall goodness of fit.

The best-fitted logistic regression results (logistic regression coefficients, significance levels and odds ratios) for $D P, P S$ and $S G$ using only map instead of plot-based predictor variables (i.e., $\log _{10}$ DTW, mapped classes for wetland/upland and forest type; Table 2) are listed in Table 7. Among these predictor variables, $P S$ and $D P$ increased while $S G$ decreased with increasing $\log$ $\log _{10}$ DTW. The wetland specification also discriminated against $D P$ and $P S$. Without the wetland variable, $\log \log _{10}$ DTW would be the strongest predictor 
Table 4. Moss presence probability models (HOF models II to V, Figure 5 ) for the more frequent species of this study ( $\mathrm{n}>50)$ : best-fitted parameters, goodness of fitness indicators $\left(\mathrm{R}^{2}\right.$ and $\mathrm{P}$ values), with Model III maximum response position for DTW, slope, canopy closure, and forest litter depth.

\begin{tabular}{|c|c|c|c|c|c|c|c|c|c|}
\hline \multirow{2}{*}{$\begin{array}{c}\text { Regression } \\
\text { Variable }\end{array}$} & \multirow{2}{*}{$\begin{array}{c}\text { Moss } \\
\text { Species }\end{array}$} & \multirow{2}{*}{ Type } & \multicolumn{4}{|c|}{ HOF Model Parameters } & \multirow{2}{*}{$R^{2}$} & \multirow{2}{*}{ P-value } & \multirow{2}{*}{$\begin{array}{l}\text { Max. of Mode } \\
\text { III at: }\end{array}$} \\
\hline & & & a & b & c & d & & & \\
\hline \multirow{7}{*}{ DTW } & $B T$ & III & 3.47 & -10.85 & 2.15 & & 0.82 & 0.002 & 0.59 to $25 \mathrm{~m}^{*}$ \\
\hline & $D P$ & IV & -6.26 & 7.24 & 4.87 & & 0.98 & 0.000 & $4.11 \mathrm{~m}$ \\
\hline & $H S$ & IV & -1.96 & 4.26 & 3.76 & & 0.20 & 0.266 & $1.91 \mathrm{~m}$ \\
\hline & $P C$ & IV & 2.49 & -1.22 & & & 0.61 & 0.023 & $4.47 \mathrm{~m}$ \\
\hline & $P S$ & IV & -5.37 & 5.44 & 3.35 & & 0.99 & 0.000 & $5.31 \mathrm{~m}$ \\
\hline & $S F$ & III & -1.1 & 5.65 & 0.83 & & 0.9 & 0.000 & 0.01 to $0.02 \mathrm{~m}^{*}$ \\
\hline & $S G$ & III & -6.67 & 11 & -0.1 & & 0.99 & 0.000 & $0.01 \mathrm{~m}$ \\
\hline \multirow{7}{*}{ Slope } & $B T$ & III & 1.46 & -53.4 & 2.11 & & 0.16 & 0.433 & 3.2 to $47 \%^{*}$ \\
\hline & $D P$ & $\mathrm{~V}$ & 0.33 & 1.31 & 1.09 & 26.55 & 0.69 & 0.041 & $8.0 \%$ \\
\hline & $H S$ & V & 1.6 & 2.81 & 2.92 & 57.89 & 0.77 & 0.021 & $4.9 \%$ \\
\hline & $P C$ & IV & -0.97 & 4.13 & 1.62 & & 0.19 & 0.393 & $14.7 \%$ \\
\hline & $P S$ & IV & -3.57 & 5.86 & 1.2 & & 0.63 & 0.060 & $19.2 \%$ \\
\hline & $S F$ & II & 1.57 & 21.31 & & & 0.94 & 0.001 & $0.0 \%$ \\
\hline & $S G$ & II & -0.21 & 13.07 & & & 0.97 & 0.000 & $0.0 \%$ \\
\hline \multirow{7}{*}{$\begin{array}{l}\text { Canopy } \\
\text { Closure }\end{array}$} & $B T$ & IV & -3.87 & 6.06 & 4.61 & & 0.85 & 0.003 & $70 \%$ \\
\hline & $D P$ & V & -1.56 & 2.96 & 2.14 & 7.21 & 0.64 & 0.031 & $49 \%$ \\
\hline & $H S$ & V & -16.39 & 18.91 & 4.19 & 3.54 & 0.74 & 0.013 & $78 \%$ \\
\hline & $P C$ & IV & -1.59 & 3.69 & 2 & & 0.41 & 0.112 & $49 \%$ \\
\hline & $P S$ & IV & -3.85 & 4.81 & 1.72 & & 0.49 & 0.079 & $58 \%$ \\
\hline & $S F$ & V & 1.05 & 6.86 & 0.87 & 46.66 & 0.15 & 0.385 & $6 \%$ \\
\hline & $S G$ & II & 0.22 & 1.55 & & & 0.95 & 0.000 & $0 \%$ \\
\hline \multirow{7}{*}{ Litter Depth } & $B T$ & V & 1.38 & 6.44 & 1.17 & 100 & 0.84 & 0.004 & $0.5 \mathrm{~cm}$ \\
\hline & $D P$ & V & -0.17 & 6.78 & 1.14 & 100 & 0.84 & 0.004 & $0.6 \mathrm{~cm}$ \\
\hline & $H S$ & V & 1.56 & 7.19 & 1.06 & 100 & 0.53 & 0.064 & $0.5 \mathrm{~cm}$ \\
\hline & $P C$ & IV & -1.25 & 12.57 & 1.64 & & 0.86 & 0.003 & $1.5 \mathrm{~cm}$ \\
\hline & $P S$ & V & -1.06 & 9.79 & 0.91 & 100 & 0.92 & 0.001 & $0.6 \mathrm{~cm}$ \\
\hline & $S F$ & II & 2.11 & 11.85 & & & 0.66 & 0.026 & $0.0 \mathrm{~cm}$ \\
\hline & $S G$ & II & 0.01 & 14.26 & & & 0.87 & 0.002 & $0.0 \mathrm{~cm}$ \\
\hline
\end{tabular}

variable for each of these species. All three species were additionally favored to occur under SW coverage, with MX also contributing to the presence of $P S$, only weakly so for $D P$, but not at all for $S G$.

Details about the goodness-of-fit of the logistic regression models in Table 7 are presented in Table 8. This table shows that the best-fitted models (i) are highly significant by way the likelihood ratio tests $(p<0.001)$, (ii) confirm that the results are not due to chance alone (AUC > 0.78), and (iii) account for the overall variations in moss absence and presence although the pseudo $\mathrm{R}^{2}$ indices remain low. 
Table 5. Best-fitted logistic regression results for seven moss species (CC: Canopy Closure; SW: Softwoods; MX: Mixedwoods).

\begin{tabular}{|c|c|c|c|c|c|}
\hline $\begin{array}{l}\text { Moss } \\
\text { species }\end{array}$ & Predictor variables & $\begin{array}{l}\text { Regression } \\
\text { Coefiecients }\end{array}$ & Std. Error of Estimate & Chi-Square & P-Value \\
\hline \multirow{6}{*}{$\begin{array}{c}\mathrm{BZ} \\
\mathrm{N}=76\end{array}$} & Constant & -4.367 & 0.518 & 71.116 & $<.0001$ \\
\hline & L-Layer & -0.296 & 0.119 & 6.157 & 0.0131 \\
\hline & Mound & 0.964 & 0.264 & 13.314 & 0.0003 \\
\hline & $\mathrm{CC}$ & 0.491 & 0.092 & 28.58 & $<0.0001$ \\
\hline & Wetland & -0.866 & 0.328 & 6.966 & 0.0083 \\
\hline & SW & 0.9 & 0.314 & 8.23 & 0.0041 \\
\hline \multirow{8}{*}{$\begin{array}{c}\mathrm{DP} \\
\mathrm{N}=233\end{array}$} & Constant & -1.154 & 0.393 & 8.626 & 0.0033 \\
\hline & L-Layer & -0.254 & 0.078 & 10.515 & 0.0012 \\
\hline & Mound & 0.462 & 0.18 & 6.56 & 0.0104 \\
\hline & $\mathrm{CC}$ & -0.107 & 0.059 & 3.303 & 0.0691 \\
\hline & $\log _{10}$ DTW & 0.604 & 0.151 & 16.076 & $<0.0001$ \\
\hline & Wetland & -2.536 & 0.291 & 75.914 & $<0.0001$ \\
\hline & SW & 1.491 & 0.331 & 20.345 & $<0.0001$ \\
\hline & MX & 0.659 & 0.361 & 3.341 & 0.0676 \\
\hline \multirow{5}{*}{$\begin{array}{c}\mathrm{HS} \\
\mathrm{N}=64\end{array}$} & Constant & -4.977 & 0.487 & 104.645 & $<0.0001$ \\
\hline & L-Layer & -0.246 & 0.127 & 3.764 & 0.0524 \\
\hline & Mound & 0.728 & 0.274 & 7.031 & 0.008 \\
\hline & $\mathrm{CC}$ & 0.482 & 0.087 & 30.825 & $<0.0001$ \\
\hline & SW & 1.273 & 0.358 & 12.635 & 0.0004 \\
\hline \multirow{4}{*}{$\begin{array}{c}\mathrm{PC} \\
\mathrm{N}=137\end{array}$} & Constant & -2.005 & 0.174 & 133.034 & $<0.0001$ \\
\hline & L-Layer & -0.204 & 0.078 & 6.915 & 0.0085 \\
\hline & Mound & 0.923 & 0.193 & 22.784 & $<0.0001$ \\
\hline & $\log _{10}$ DTW & 0.481 & 0.122 & 15.445 & $<0.0001$ \\
\hline \multirow{7}{*}{$\begin{array}{c}\text { PS } \\
\mathrm{N}=328\end{array}$} & Constant & -1.48 & 0.344 & 18.534 & $<0.0001$ \\
\hline & L-Layer & -0.449 & 0.077 & 34.224 & $<0.0001$ \\
\hline & Mound & 1.042 & 0.171 & 37.15 & $<0.0001$ \\
\hline & $\log _{10}$ DTW & 0.814 & 0.138 & 34.761 & $<0.0001$ \\
\hline & Wetland & -1.623 & 0.22 & 54.415 & $<0.0001$ \\
\hline & SW & 1.951 & 0.311 & 39.232 & $<0.0001$ \\
\hline & MX & 1.284 & 0.337 & 14.542 & 0.0001 \\
\hline \multirow{4}{*}{$\begin{array}{c}\mathrm{SF} \\
\mathrm{N}=63\end{array}$} & Constant & -2.203 & 0.269 & 66.998 & $<0.0001$ \\
\hline & L-Layer & -0.352 & 0.169 & 4.325 & 0.0376 \\
\hline & $\mathrm{CC}$ & -0.862 & 0.2 & 18.635 & $<0.0001$ \\
\hline & $\log _{10}$ DTW & -0.677 & 0.185 & 13.41 & 0.0003 \\
\hline \multirow{6}{*}{$\begin{array}{c}S G 1 \\
N=301\end{array}$} & Constant & -1.144 & 0.223 & 26.432 & $<0.0001$ \\
\hline & L-Layer & -0.787 & 0.103 & 57.845 & $<0.0001$ \\
\hline & Mound & -0.397 & 0.165 & 5.81 & 0.0159 \\
\hline & $\log _{10}$ DTW & -0.423 & 0.117 & 13.138 & 0.0003 \\
\hline & Wetland & 0.807 & 0.203 & 15.743 & $<0.0001$ \\
\hline & SW & 0.741 & 0.178 & 17.338 & $<0.0001$ \\
\hline \multirow{6}{*}{$\begin{array}{c}S G 2 \\
N=301\end{array}$} & Constant & -0.222 & 0.246 & 0.812 & 0.3674 \\
\hline & L-Layer & -0.741 & 0.099 & 55.991 & $<0.0001$ \\
\hline & Mound & -0.373 & 0.17 & 4.827 & 0.028 \\
\hline & Slope & -0.189 & 0.029 & 42.878 & $<0.0001$ \\
\hline & Wetland & 0.691 & 0.185 & 13.942 & 0.0002 \\
\hline & SW & 0.688 & 0.18 & 14.646 & 0.0001 \\
\hline
\end{tabular}


Also shown in Table 8 are the goodness-of-fit results for model validation, to indicate that the models derived from the 11 sampling locations across New Brunswick predict the $D P, P S$ and $S G$ occurrences for the validation location

Table 6. Summary of the best-fitted positive (+) and negative (-) trends in Table 5.

\begin{tabular}{|c|c|c|c|c|c|c|c|}
\hline & L-layer & Mound & $\mathrm{CC}$ & $\log _{10}$ DTW & Wetland & SW & MX \\
\hline $\mathrm{BZ}$ & - & + & + & & - & + & \\
\hline $\mathrm{DP}$ & - & + & - & + & - & + & \\
\hline HS & - & + & + & & & + & \\
\hline PC & - & + & & + & & & \\
\hline PS & - & + & & + & - & + & + \\
\hline SF & - & & & - & & & \\
\hline SG1 & - & - & & - & + & + & \\
\hline SG2 & - & - & & - (slope) & + & + & \\
\hline $\begin{array}{c}\text { Number of variables with } \\
\text { positive trends }\end{array}$ & & 7 & 2 & 3 & 2 & 6 & 1 \\
\hline $\begin{array}{c}\text { Number of variables with } \\
\text { negative trends }\end{array}$ & 8 & & 1 & 3 & 3 & & \\
\hline
\end{tabular}

Table 7. Best-fitted binary multivariate logistic regression parameters including their statistical significance and odds ratios to predict the moss presence/absence probability responses as affected by $\log _{10}$ DTW, wetland versus upland location, and forest type (SW, MX).

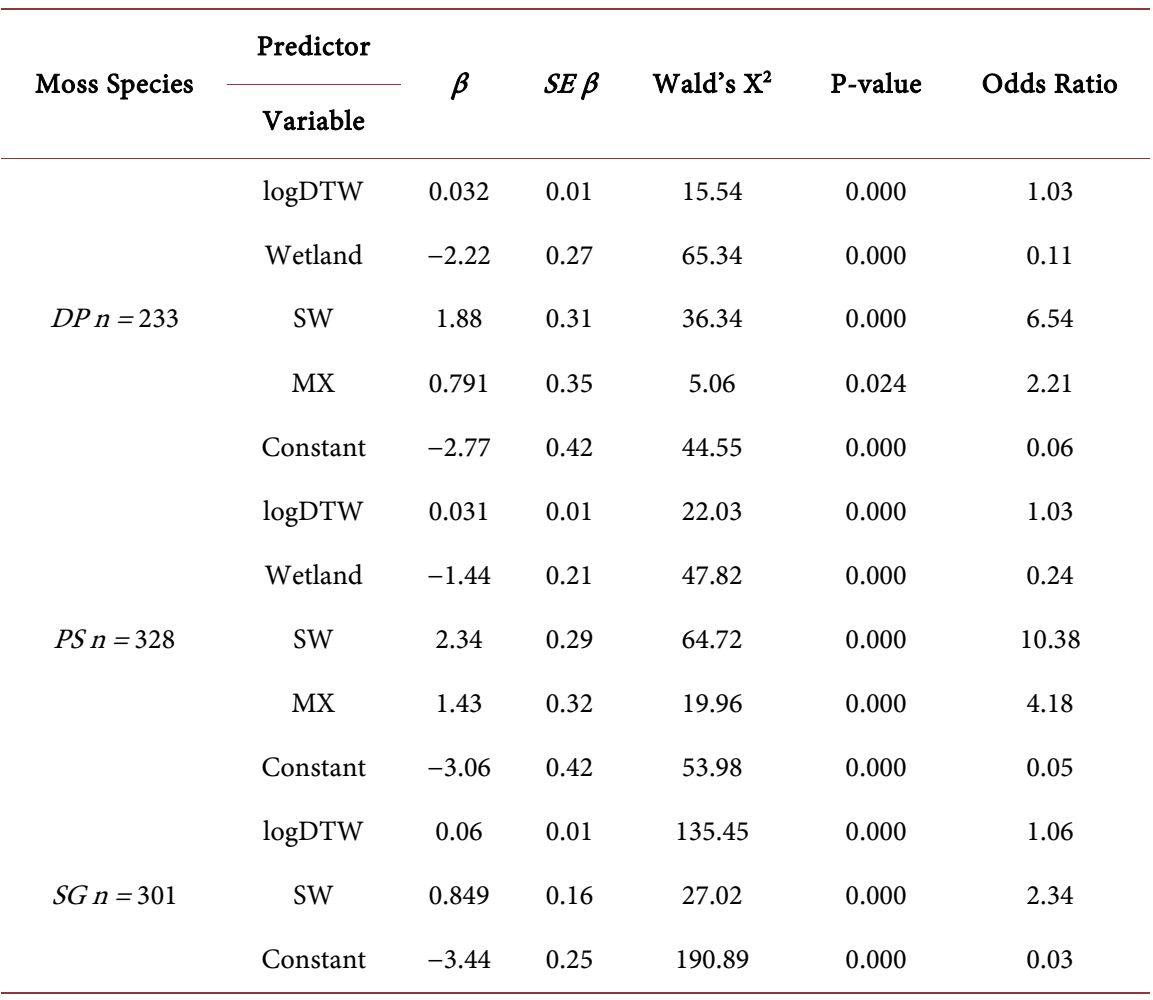


Table 8. Goodness-of-fit comparisons (Likelyhood Ratio Test, Cox \& Snell and Nagelkerke $\mathrm{R}^{2}$ analogues, and AUC) for the logistic regression models in Table 7 for $D P, P S$ and $S G$.

\begin{tabular}{|c|c|c|c|c|c|c|}
\hline & \multirow{2}{*}{$\begin{array}{c}\text { Moss } \\
\text { Species }\end{array}$} & \multicolumn{3}{|c|}{ Likelihood Ratio Test } & \multicolumn{2}{|c|}{$\mathbf{R}^{2}$-type Indices } \\
\hline & & $X^{2}$ & df & $\mathrm{P}$-value & Cox \& Snell & Nagelkerke \\
\hline \multirow{8}{*}{$\begin{array}{c}\text { Model } \\
\text { Development }\end{array}$} & $D S$ & 289.25 & 4 & 0.000 & 0.26 & 0.38 \\
\hline & $P S$ & 299.75 & 4 & 0.000 & 0.26 & 0.37 \\
\hline & $S G$ & 210.77 & 2 & 0.000 & 0.19 & 0.27 \\
\hline & & \multirow{2}{*}{ AUC } & \multirow{2}{*}{$\begin{array}{l}\text { Std. } \\
\text { Error }\end{array}$} & \multirow{2}{*}{ Sig. } & \multicolumn{2}{|c|}{ 95\% Confidence Intervals } \\
\hline & & & & & Lower Bound & Upper Bound \\
\hline & $D S$ & 0.84 & 0.013 & 0.000 & 0.82 & 0.87 \\
\hline & $P S$ & 0.82 & 0.014 & 0.000 & 0.79 & 0.84 \\
\hline & $S G$ & 0.78 & 0.015 & 0.000 & 0.75 & 0.8 \\
\hline \multirow{3}{*}{$\begin{array}{c}\text { Model } \\
\text { Validation }\end{array}$} & $D S$ & 0.81 & 0.027 & 0.000 & 0.75 & 0.86 \\
\hline & $P S$ & 0.82 & 0.026 & 0.000 & 0.77 & 0.87 \\
\hline & $S G$ & 0.75 & 0.029 & 0.000 & 0.69 & 0.81 \\
\hline
\end{tabular}

Table 9. Observed and predicted frequencies for bryophyte presence by logistic regression analysis (LR) across the 11 New Brunswick locations that were used for model development, and the Fredericton location used for model validation (Figure 1).

\begin{tabular}{|c|c|c|c|c|c|c|c|c|c|c|}
\hline & \multirow{2}{*}{$\begin{array}{l}\text { Moss } \\
\text { species }\end{array}$} & \multirow{2}{*}{ Actual } & \multicolumn{2}{|c|}{ Predicted } & \multirow{2}{*}{ Correct \% } & \multirow{2}{*}{$\begin{array}{c}\text { False } \\
\text { Positives \% }\end{array}$} & \multirow{2}{*}{$\begin{array}{c}\text { False } \\
\text { Negatives \% }\end{array}$} & \multirow{2}{*}{$\begin{array}{c}\text { Overall } \\
\text { Correct \% }\end{array}$} & \multirow{2}{*}{$\begin{array}{l}\text { Prob. by } \\
\text { Chance } \\
\text { Criterion }\end{array}$} & \multirow{2}{*}{$\begin{array}{l}\text { Prob. by } \\
\text { Chance }\end{array}$} \\
\hline & & & 0 & 1 & & & & & & \\
\hline \multirow{6}{*}{$\begin{array}{c}\text { Model } \\
\text { development }\end{array}$} & \multirow{2}{*}{$D P$} & 0 & 657 & 90 & 0.88 & \multirow[b]{2}{*}{0.43} & \multirow{2}{*}{0.14} & \multirow[b]{2}{*}{0.80} & \multirow{2}{*}{0.80} & \multirow[b]{2}{*}{0.64} \\
\hline & & 1 & 106 & 127 & 0.55 & & & & & \\
\hline & \multirow{2}{*}{$P S$} & 0 & 539 & 113 & 0.83 & \multirow{2}{*}{0.36} & \multirow{2}{*}{0.19} & \multirow{2}{*}{0.76} & \multirow{2}{*}{0.69} & \multirow{2}{*}{0.55} \\
\hline & & 1 & 123 & 205 & 0.63 & & & & & \\
\hline & \multirow{2}{*}{$S G$} & 0 & 582 & 97 & 0.86 & \multirow{2}{*}{0.39} & \multirow{2}{*}{0.17} & \multirow{2}{*}{0.73} & \multirow{2}{*}{0.72} & \multirow{2}{*}{0.57} \\
\hline & & 1 & 165 & 136 & 0.45 & & & & & \\
\hline \multirow{6}{*}{$\begin{array}{c}\text { Model } \\
\text { validation }\end{array}$} & \multirow{2}{*}{$D P$} & 0 & 254 & 11 & 0.96 & \multirow{2}{*}{0.42} & \multirow{2}{*}{0.15} & \multirow{2}{*}{0.83} & \multirow{2}{*}{0.87} & \multirow{2}{*}{0.70} \\
\hline & & 1 & 45 & 15 & 0.25 & & & & & \\
\hline & \multirow{2}{*}{$P S$} & 0 & 250 & 5 & 0.98 & \multirow{2}{*}{0.24} & 018 & $09 ?$ & 082 & 65 \\
\hline & & 1 & 54 & 16 & 0.23 & & 0.18 & 0.82 & 0.82 & 0.03 \\
\hline & $S G$ & 0 & 88 & 47 & 0.65 & 026 & 0 & 067 & $0<4$ & 0,1 \\
\hline & $3 G$ & 1 & 59 & 131 & 0.69 & 0.20 & 0.4 & $0.0 \%$ & 0.04 & 0.31 \\
\hline
\end{tabular}

more or less equally well. The corresponding classification results are listed in Table 9 by number of cases correctly and incorrectly predicted. The accuracy ranged from $67 \%$ to $83 \%$, with false positives and negatives amounting to $18 \%$ to $42 \%$. The overall classification accuracy exceeded the probability by chance 
alone at $76.8 \%$, with the significance level reached at $75.3 \%$. The average level of probability by chance alone was $60.3 \%$.

\section{Discussion}

\subsection{DTW}

The species response frequencies to the DTW-modelled variations in soil moisture regime are generally in agreement with the following expectations (Figure 4): hydric mosses such as $S F$ are commonly found on wetlands and on poorly drained soils where DTW is low (i.e., $<25 \mathrm{~cm}$ ). In comparison, $S G$ spreads widely on fens, bogs and forested wetlands, but also grows in wet microsites (pits) on moderately well-drained upland forests [49]. In contrast, $B T, D P, H S$, $P S$ and $P C$ prefer moist to dry sites on uplands and on mounds (Figure 5). In combination, bryophytes often grow intermixed with each other, because of similar survival requirements [12] [50]. Hence, many of their response curves in Figure 5 overlap to varying degrees. For example, $D P$ and $P S$ typically occur together, with optimal DTW responses at 4 to $5 \mathrm{~m}$. This also reflects their common occurrences on dry woodland towards the margins of swamps, and also on stumps [13]. While all of the species gravitated towards optimal DTW locations, $H S$ and $B T$ did only weakly so. This could be due to two reasons: (i) these species are found on suitable microhabitats across a wide range of substrate conditions [17]; (ii) their occurrence frequencies, however, are low and widely spread across the DTW from 0.6 to $25 \mathrm{~m}$.

\subsection{Slope \& Aspect}

Since slope is in part correlated with DTW (slope $=1.57 \mathrm{DTW} ; \mathrm{R}^{2}=0.51$ ), there is a general similarity between moss species occurrence with respect to changing slope and DTW, with $S G$ gravitating towards flat locations, as observed elsewhere [51], with Sphagnum mosses generally present only on the lowest and wettest locations [52]. The other species prefer upland locations, and here they are more frequent on mounds than in pits. Although aspect has the potential to affect microclimates and plant species distribution [53], no such dependence was detected in this study, possible due to small sample size, and the preponderance of diffuse light under forest canopies

\subsection{Ecosite}

While there are clear differences in moss occurrences by uplands versus wetlands (Figure 5, top), this was much less the case when the occurrence frequencies were analysed by ecosite type. In part, this may be due to the sampling unevenness by ecosite type. Typically, regression results across categorical variables need to be well and evenly represented by sample size [40]. Bryophytes species, however, are not evenly distributed across varying wetland and upland conditions [24] [54] [55]. For this study, upland and wetland locations were essentially equally represented ( $\mathrm{n}=497$ versus 483 , respectively), but the wetland locations 
were split into nine categories, with $\mathrm{n}$ per category ranging from 14 (meadows) to 129 (fens).

\subsection{Vegetation Type}

The softwood stands surveyed generally had abundant bryophyte mats, thereby rendering SW to be the dominant vegetation type variable to predict the occurrence of $D P, P S$ and $S G$. In general, $S G$ is associated with wet coniferous forests dominated by black spruce (Picea mariana), tamarack (Larix laricina), and balsam fir (Abies balsamea). In contrast, $P S$ and $D P$ are mostly associated with upland forests dominated by red spruce (Picea rubens), eastern hemlock (Tsuga canadensis), balsam fir, and white pine (Pinus strobus). $P S$ and $D P$ were also correlated with the MX variable, which represents early to late successional mixedwood forests dominated by red maple (Acer rubrum), white birch (Betula papyrifera), and balsam fir, and later successional stages composed of yellow birch (Betula alleghaniensis), red spruce or eastern hemlock. Within these forests, ground flora is generally herbaceous and accompanied with bryophyte diversity [25]. In pure hardwood stands, ground flora is dominated by shrubs and ferns. Bryophytes, when present, are generally constrained to grow on exposed coarse woody debris, likely due to moss-suppressing leaf litter cover elsewhere [25].

\subsection{Leaf Litter Depth, and Mound Versus Pit Effects}

Bryophytes growing on the forest floor have been shown to be negatively affected by deciduous leaf cover [17] [56]. In the present study, all species occurred less frequently with increasing litter depth above $0.5-1 \mathrm{~cm}$. The effect was almost as significant as the moss occurrence relationships with DTW. Some bryophyte species such as $D P$ and $P C$ appear to be more adapted to growing through broadleaf litter [11]. Of the species included in this study, none were frequently found where the depth of the leaf litter was greater than $6 \mathrm{~cm}$ thick, although some species fared better than others in the $>6 \mathrm{~cm}$ zone. In part, this could be due to their growth form. Studies have found that mosses with upright (acrocarpous) growth forms such as $D P$ and $P C$ respond better to litter burial than creeping mosses with prostrate (pleurocarpous) growth forms [56]. In addition, bryophyte community composition is closely related to microhabitat [57], thereby leading to the mound versus pit related leaf litter distributions shown in Figure 5. In contrast, macro-habitat features related to macro changes in topography, aspect, and canopy closure tend to be less influential.

\subsection{Canopy Closure}

Forest canopy closure affects levels of light and precipitation reaching the forest floor, creating a complex microclimatic gradient, with differing levels of light, temperature, and humidity [5]. Canopy closure helps explain some variation in bryophyte occurrence, particularly for Sphagnum mosses, which were typically found in wetlands with little to no tree canopy, but remain constantly moist in 
full sun. In dry and fully exposed environments, bryophytes become metabolically inactive or desiccate altogether [58]. Aside from Sphagnum species, most bryophytes require at least small amounts of shade [59]. Heavy shading, however, reduces moss occurrences [5] [56] [59] [60] [61] [62], with bryophyte mortality increasing with increasing aspen leaf coverage, mainly due to shading and lack of phytochemical responses [59], with light/shade effects thought to become growth-limiting once all other resource needs are met [63].

\subsection{Multiple Regression Analyses}

The best-fitted multivariate logistic regression trends in Table 5 show that litter depth, mound location, DTW, wetland versus upland type and coniferous versus deciduous forest type are the dominant positive or negative predictor variables. Generally, wetland and coniferous forest types have already been shown to influence the occurrence of bryophyte species across landscapes [2] [3] [11]. For the non-coniferous forest types, only mixedwood (MX) remained as a predictor variable for PS. Among the somewhat correlated terrain variables, DTW and wetland versus upland remained as significant predictor variables, while slope also became significant predictor variable for $S G$. Only three species were either positively $(B T, H S)$ or negatively $(D P)$ affected by canopy closure, while increasing litter depth had a negative effect on all 7 species.

In total, only up to $30 \%$ of the plot-by-plot moss occurrences could be quantified by way of the above procedures and analyses. The unexplained sampling variations would, for the most part, be due to local variations in substrate and vegetation mix conditions as these vary locally on account of stochastically varying processes pertaining to litterfall, shading, canopy throughfall, and vegetation growth and competition [64] [65]. The mix in resolution and the approximate nature of some of the predictor variables would also contribute to the unexplained variations, as follows:

- The values for canopy closure, wetland and forest type are based on assuming uniform conditions across each sampling location. Hence, these data do not reflect the meter-by-meter differences in vegetation type and canopy shading across the forest floor.

- In contrast, the DEM-derived DTW variable and the field determined litter depth and mound versus pit location are matching the $1 \mathrm{~m}^{2}$ sampling procedure quite closely. However, using slope as a predictor variable produced best results for $S G$ but only so after $20 \mathrm{~m}$ focal smoothing.

- Sampling was done unevenly across vegetation type, i.e., mostly but not exclusively on softwood sites. Similarly, bogs were more frequently sampled than fens, while steep riparian zones were less frequently sampled. Riparian moss species such as Climacium dendroides and Aulacomnium palustre were therefore under-sampled. More equally distributed samples could have been obtained by stratifying by more than one environmental variable, e.g. forest type or wetland type in addition to stratifying by DTW zones alone.

- There is a 3 to 5 meter inaccuracy of determining the exact sampling location 
using the hand-held GPS device.

\subsection{Model Validation}

Testing the best-fitted presence/absence models for DP, PS, and Sphagnum moss against the independent data for the University of New Brunswick Forest (Fredericton) produced an overall classification accuracy of $67 \%$ to $83 \%$. For $D P$ and $P S$, absence was better predicted than presence. Sphagnum had a particularly high percentage of false negatives ( $40 \%$, Table 9 ).

The above model results produced with the mappable predictor variables Table 2 are similar to the results produced with the plot-based predictor variables in $\mathrm{Ta}$ ble 2 for all of the sampling locations in Table 1. This similarity is illustrated
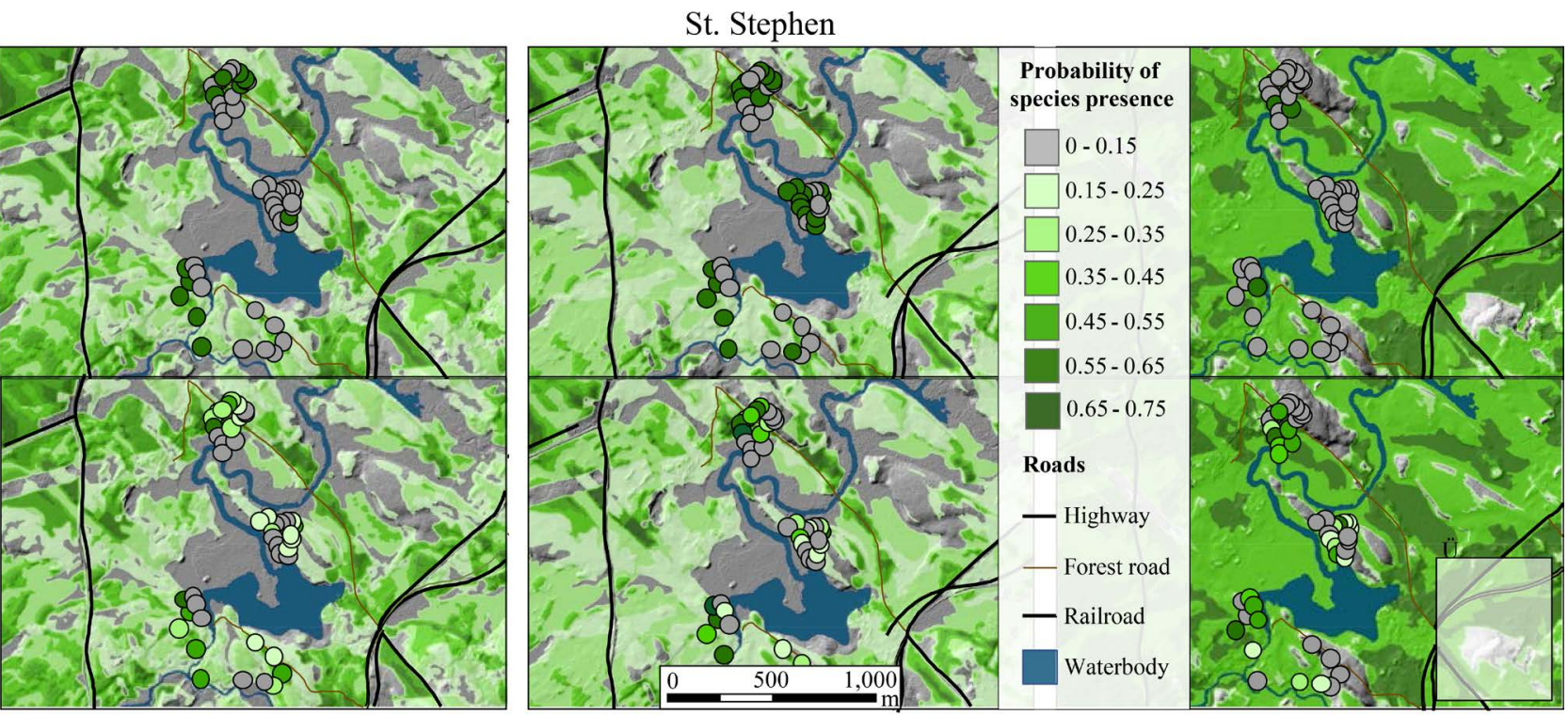

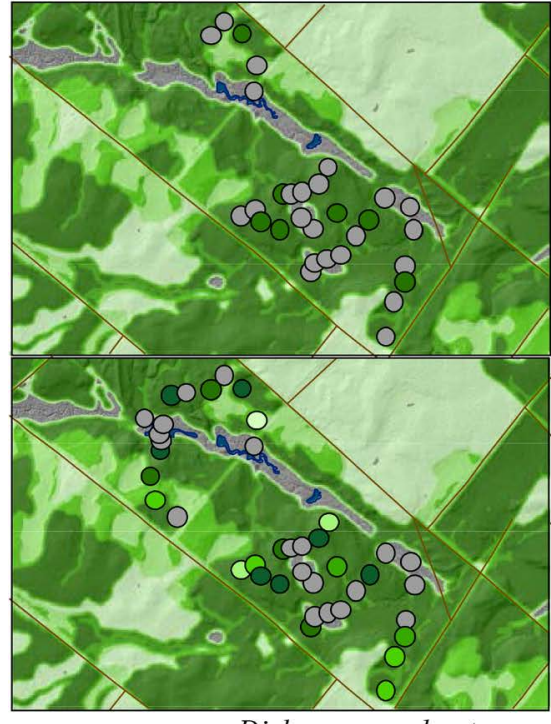

Dichranum polysetum

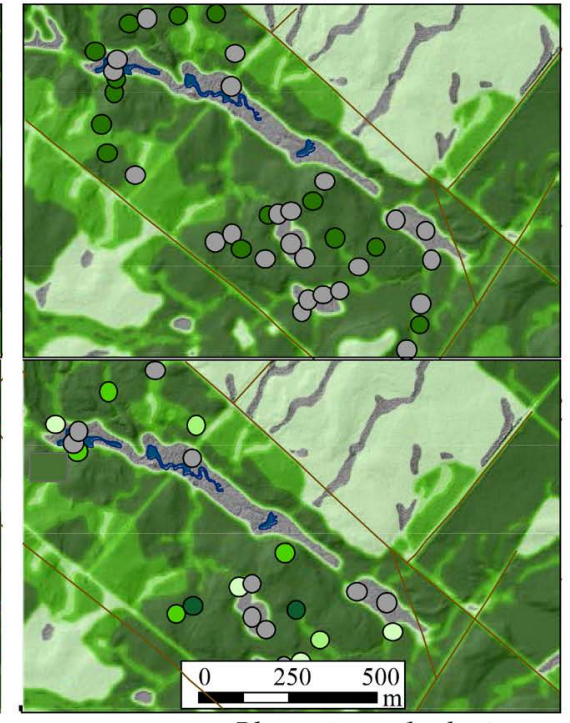

Pleurozium schreberi

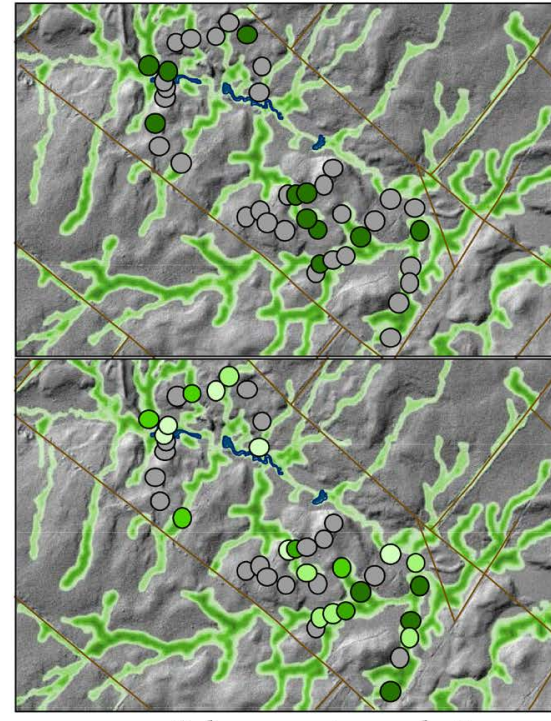

Sphagnum girgensohnii

Figure 6. Presence/absence observations (dots, top portion of each panel) and the corresponding modelled presence probability for each dot at St. Stephen (top) and at Dorn Ridge (bottom), all overlaid on the mapped probability of presence for Dichranum polysetum (left), Pleurozium schreberi (middle) and Sphagnum girgensohnii (right). 


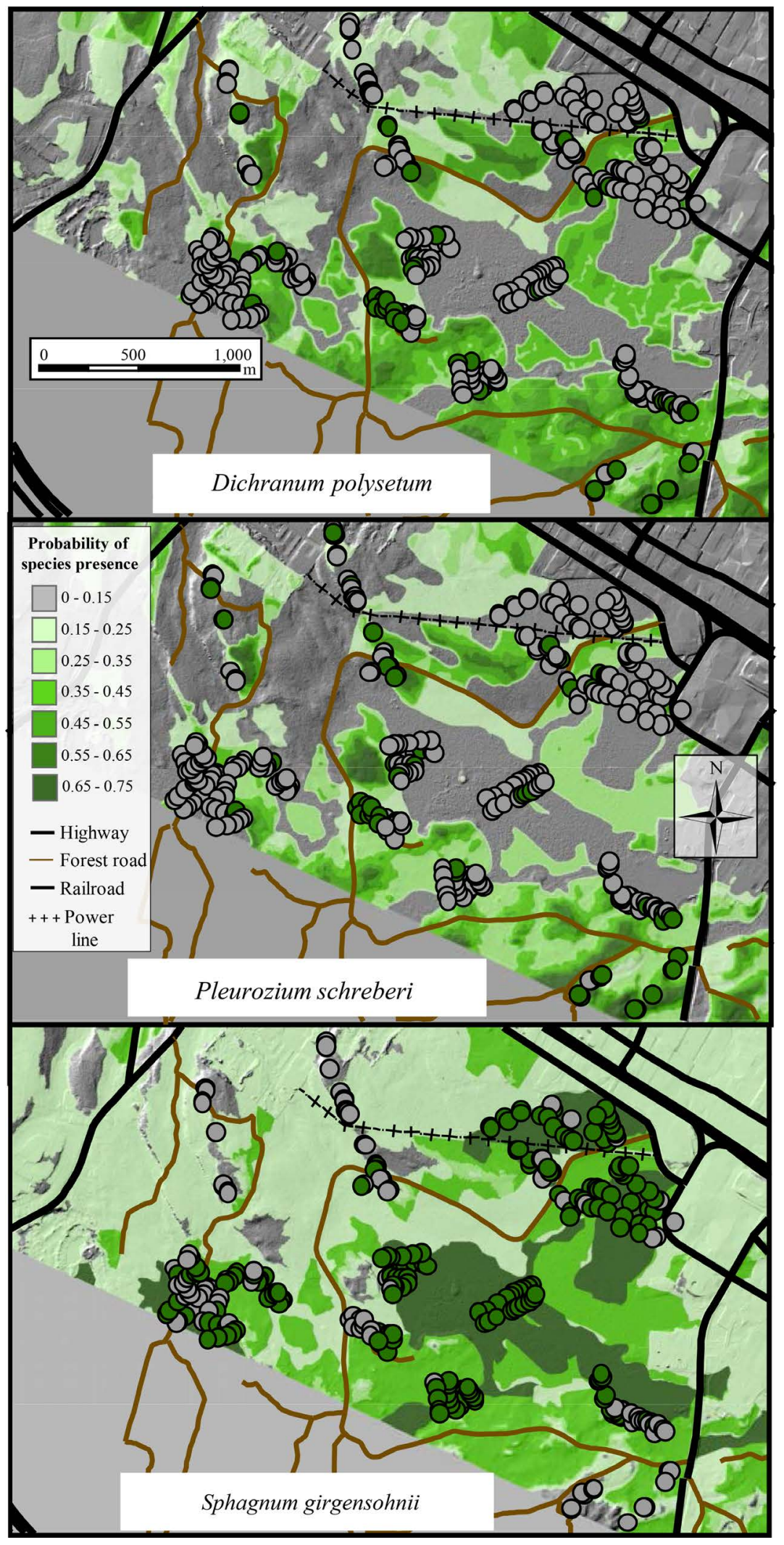

Figure 7. Presence/absence observations (dots) overlaid on the predicted presence probability map for Dichranum polysetum (top), Pleurozium schreberi (middle) and Sphagnum girgensohnii (bottom) for the sampling plots within the University of New Brunswick Forest in Fredericton (validation location). 
in Figure 6 and Figure 7 for three of these locations: St. Stephen, Dorn Ridge and Fredericton. Generally, data-derived models tend to perform less well on data that are not part of model training. For example, [66] found that only a half of data-trained models performed reasonably well when tested against independent data.

\section{Conclusions}

The question of whether changes in bryophyte distribution could be modelled and mapped was explored using univariate HOF models and a series of logistic regression models, with depth-to-water, slope, forest canopy closure, and depth of the leaf litter layer as species-specific presence/absence probability predictors. These probabilities varied by species, as expected. Along the DTW gradient, Bazzania trilobata, Dicranum polysetum, Polytrichum commune, Hylocomium splendens, and Pleurozium schreberi had a greater probability of occurrence towards the drier end of the water table gradient (well-drained forested land), whereas Sphagnum fuscum and Sphagnum girgensohnii had the reverse trend. The depth-to-water index and slope worked best as a predictor for the Sphagnum species, due to their affinity for poorly drained, flat areas. Canopy closure appears to affect the presence probability of Bazzania trilobata, Dicranum polysetum, Hylocomium splendens, and Sphagnum girgensohnii. All species had considerably lower occurrences with increased depth of deciduous leaf litter.

The above results suggest that the presence/absence probabilities of bryophyte species can be predicted using a combination of environmental variables, with the depth-to-water index as a prominent predictor variable for at least some of the species. This research therefore extends some of the existing knowledge regarding common bryophyte responses to environmental gradients pertaining to variations in shading, exposure, moisture and nutrient availabilities, and substrate quality and conditions. While this work is limited to New Brunswick, the sampling effort reached across several upland/wetland combinations under maritime climate. This suggests that the approach taken and the models so produced could be useful for estimating the presence/absence probability of common moss species across New Brunswick and elsewhere under similar climate conditions.

\section{Acknowledgements}

This research was in part supported by the Environmental Trust Fund of New Brunswick and by the Natural Sciences and Engineering Research Council of Canada (NSERC: Discovery Grant, Canada Graduate Scholarship). Special thanks go to the Forest Watershed Research Centre at UNB for support in processing the LiDAR-derived wet areas maps (Jae Ogilvie, Doug Hiltz) and field sampling (Matthew Bolton, Benno Künzig, Friedrich Johan Wüthrich).

\section{References}

[1] Jenkins, R.B. and Frazier, P.S. (2010) High-Resolution Remote Sensing of Upland Swamp Boundaries and Vegetation for Baseline Mapping and Monitoring. Wet- 
lands, 30, 531-540. https://doi.org/10.1007/s13157-010-0059-1

[2] Vanderpoorten, A., Sotiaux, A. and Engels, P. (2005) A GIS-Based Survey for the Conservation of Bryophytes at the Landscape Scale. Biological Conservation, 121, 189-194. https://doi.org/10.1016/j.biocon.2004.04.018

[3] Frego, K.A. and Carleton, T.J. (1995) Microsite Conditions and Spatial Pattern in a Boreal Bryophyte Community. Canadian Journal of Botany, 73, 544-551. https://doi.org/10.1139/b95-056

[4] Fenton, N.J., Frego, K.A. and Sims, M.R. (2003) Changes in Forest Floor Bryophyte (Moss and Liverwort) Communities 4 Years after Forest Harvest. Canadian Journal of Botany, 81, 714-731. https://doi.org/10.1139/b03-063

[5] Fenton, N.J. and Frego, K.A. (2005) Bryophyte (Moss and Liverwort) Conservation under Remnant Canopy in Managed Forests. Biological Conservation, 122, 417-430. https://doi.org/10.1016/j.biocon.2004.09.003

[6] Delgadillo, C.M. (1992) Moss Interchange: Bryofloristic Similarities between Mexico and Colombia and the Phytogeographical Role of the Central American Bridge. The Bryologist, 95, 261-265. https://doi.org/10.2307/3243481

[7] Vanderpoorten, A. and Engels, P. (2002) The Effects of Environmental Variation on Bryophytes at a Regional Scale. Ecography, 25, 513-522.

https://doi.org/10.1034/j.1600-0587.2002.250501.x

[8] Vanderpoorten, A. and Engels, P. (2003) Patterns of Bryophyte Diversity and Rarity at a Regional Scale. Biodiversity and Conservation, 12, 545-553. https://doi.org/10.1023/A:1022476902547

[9] Belland, R.J. (2005) A Multivariate Study of Moss Distributions in Relation to Environment in the Gulf of St. Lawrence Region, Canada. Canadian Journal of Botany, 83, 243-263. https://doi.org/10.1139/b04-172

[10] Geffert, J.L., Frahm, J.-P., Barthlott, W. and Mutke, J. (2013) Global Moss Diversity: Spatial and Taxonomic Patterns of Species Richness. Journal of Bryology, 35, 1-11. https://doi.org/10.1179/1743282012Y.0000000038

[11] Carleton, T.J. (1990) Variation in Terricolous Bryophyte and Macrolichen Vegetation along Primary Gradients in Canadian Boreal Forests. Journal of Vegetation Science, 1, 585-594. https://doi.org/10.2307/3235563

[12] Evans, S.A., Halpern, C.B. and McKenzie, D. (2012) The Contributions of Forest Structure and Substrate to Bryophyte Diversity and Abundance in Mature Coniferous forests of the Pacific Northwest. The Bryologist, 115, 278-294. https://doi.org/10.1639/0007-2745-115.2.278

[13] Ireland, R.R. and Hanes, A. (1982) Moss Flora of the Maritime Provinces. National Museums of Canada, Ottawa.

[14] Belland, R.J. (2010) Mosses (Bryophyta) of the Atlantic Maritime Ecozone. In: McAlpine, D.F. and Smith, I.M., Eds., Assessment of Species Diversity in the Atlantic Maritime Ecozone, NRC Research Press, Ottawa, 179-196.

[15] Busby, J.R., Bliss, L.C. and Hamilton, C.D. (1978) Microclimate Control of Growth Rates and Habitats of the Boreal Forest Mosses, Tomenthypnum nitens and Hylocomium splendens. Ecological Monographs, 48, 95-110. https://doi.org/10.2307/2937294

[16] Conard, H.S. and Redfearn, P.L. (1979) How to Know the Mosses and Liverworts. W.C. Brown Co., Dubuque.

[17] Longton, R.E. (1992) The Role of Bryophytes and Lichens in Terrestrial Ecosystems. In: Bates, J. and Farmer, A., Eds., Bryophytes and Lichens in a Changing Environment, Oxford University Press, New York. 
[18] Rydin, H., Jeglum, J.K. and Hooijer, A. (2006) The Biology of Peatlands. Oxford University Press, Oxford. https://doi.org/10.1093/acprof:oso/9780198528722.001.0001

[19] Murphy, P.N.C., Ogilvie, J. and Arp P.A. (2009) Topographic Modelling of Soil Moisture Conditions: A Comparison and Verification of Two Models. European Journal of Soil Science, 60, 94-109. https://doi.org/10.1111/j.1365-2389.2008.01094.x

[20] Murphy, P.N.C., Ogilvie, J., Meng, F.-R., White, B., Bhatti, J.S. and Arp, P.A. (2011) Modelling and Mapping Topographic Variations in Forest Soils at High Resolution: A Case Study. Ecological Modelling, 222, 2314-2332. https://doi.org/10.1016/j.ecolmodel.2011.01.003

[21] Campbell, D.M.H., White, B. and Arp, P.A. (2013) Modeling and Mapping Soil Resistance to Penetration and Rutting Using LiDAR-Derived Digital Elevation Data. Journal of Soil and Water Conservation, 68, 460-473. https://doi.org/10.2489/jswc.68.6.460

[22] Bullock, J. (1996) Plants. In: Sutherland, W.J., Ed., Ecological Census Techniques: A Handbook, Cambridge University Press, Cambridge, 111-137.

[23] Sutherland, W.J. (2006) Ecological Census Techniques: A Handbook. Cambridge University Press, Cambridge. https://doi.org/10.1017/CBO9780511790508

[24] Gillrich, J.J., Bowman, K.C. and US Army Corps of Engineers (2010) The Use of Bryophytes as Indicators of Hydric Soils and Wetland Hydrology during Wetland Delineations in the United States.

[25] Neily, P., Basquill, S., Quigley, E., Stewart, B. and Keys, K. (2010) Forest Ecosystem Classification for Nova Scotia. Part I: Vegetation Types. Nova Scotia Department of Natural Resources, Truro.

[26] NB DNR (NB Department of Natural Resources) (2007) Appendix 1: Ecosites and Ecoelements. In: Zelazny, V.F., Ed., Our Landscape Heritage: The Story of Ecological Land Classification in New Brunswick, NB DNR, Fredericton, 331-340.

[27] NB DNR (NB Department of Natural Resources) (2006) New Brunswick Wetland Classification for 2003-2012 Photo Cycle.

[28] Murphy, P.N.C., Ogilvie, J., Connor, K. and Arp, P.A. (2007) Mapping Wetlands: A Comparison of Two Different Approaches for New Brunswick, Canada. Wetlands, 27, 846-854. https://doi.org/10.1672/0277-5212(2007)27[846:MWACOT]2.0.CO;2

[29] R Development Core Team (2011) R: A Language and Environment for Statistical Computing. R Foundation for Statistical Computing, Vienna.

[30] Jansen, F. and Oksanen, J. (2013) How to Model Species Responses along Ecological Gradients-Huisman-Olff-Fresco Models Revisited. Journal of Vegetation Science, 24, 1108-1117. https://doi.org/10.1111/jvs.12050

[31] Oksanen, J. and Minchin, P.R. (2002) Continuum Theory Revisited: What Shape Are Species Responses along Ecological Gradients? Ecological Modelling, 157, 119 129. https://doi.org/10.1016/S0304-3800(02)00190-4

[32] Akaike, H. (1974) A New Look at the Statistical Model Identification. IEEE Transactions on Automatic Control, 19, 716-723. https://doi.org/10.1109/TAC.1974.1100705

[33] Burnham, K. and Anderson, D.R. (2002) Model Selection and Multi-Model Inference: A Practical Information-Theoretic Approach. Springer, New York.

[34] Stockwell, D. and Peterson, A. (2002) Effects of Sample Size on the Performance of Species Distribution Models. Ecological Modelling, 148, 1-13.

https://doi.org/10.1016/S0304-3800(01)00388-X 
[35] Coudon, C. and Gégout, J.C. (2007) Quantitative Prediction of the Distribution and Abundance of Vaccinium myrtillus with Climatic and Edaphic Factors. Journal of Vegetation Science, 18, 517-524. https://doi.org/10.1111/j.1654-1103.2007.tb02566.x

[36] Franklin, J. (2009) Mapping Species Distributions. Cambridge University Press, Cambridge.

[37] Huisman, J., Olff, H. and Fresco, L.F.M. (1993) A Hierarchical Set of Models for Species Response Analysis. Journal of Vegetation Science, 4, 37-46. https://doi.org/10.2307/3235732

[38] Hosmer, D.W. and Lemeshow, S. (1989) Applied Logistic Regression. Wiley Interscience Publication, Chichester.

[39] Hosmer, D.W., Lemeshow, S. and Sturdivant, R.X. (2013) Applied Logistic Regression. 3rd Edition, Wiley, Hoboken. https://doi.org/10.1002/9781118548387

[40] Tutz, G. (2012) Regression for Categorical Data. Cambridge University Press, Cambridge.

[41] Mansfield, E.R. and Helms, B.P. (1982) Detecting Multicollinearity. The American Statistician, 36, 158-160. https://doi.org/10.1080/00031305.1982.10482818

[42] Nagelkerke, N.J.D. (1991) A Note on a General Definition of the Coefficient of Determination. Biometrika, 78, 691-692. https://doi.org/10.1093/biomet/78.3.691

[43] Hanley, J.A. and McNeil, B.J. (1982) The Meaning and Use of the Area under a Receiver Operating Characteristic (ROC) Curve. Radiology, 143, 29-36. https://doi.org/10.1148/radiology.143.1.7063747

[44] White, J.L. (2013) Logistic Regression Model Effectiveness: Proportional Chance Criteria and Proportional Reduction in Error. Journal of Contemporary Water Research and Education, 2, 4-10.

[45] SRI (2009) ArcGIS Desktop: Release 10.2. Environmental Systems Research Institute, Redlands.

[46] Ringius, G.S. and Sims, R.A. (1997) Indicator Plant Species in Canadian Forests. Canadian Forest Service, Ottawa, 218 p.

[47] Lawesson, E.L. and Oksanen, J. (2002) Niche Characteristics of Danish Woody Species as Derived from Coenoclines. Journal of Vegetation Science, 13, 279-290. https://doi.org/10.1111/j.1654-1103.2002.tb02048.x

[48] Rydgren, K., Økland, R.H. and Økland, T. (2003) Species Response Curves along Environmental Gradients. A Case Study from SE Norwegian Swamp Forests. Journal of Vegetation Science, 14, 869-880. https://doi.org/10.1111/j.1654-1103.2003.tb02220.x

[49] Tiner, R.W. (2005) In Search of Swampland: A Wetland Sourcebook and Field Guide. 2nd Edition, Rutgers University Press, New Brunswick.

[50] Kent, M. (2012) Vegetation Description and Data Analysis: A Practical Approach. 2nd Edition, John Wiley \& Sons, Chichester.

[51] Michel, P., Overton, J.M., Mason, N.W.H., Hurst, J.M. and Lee, W.G. (2010) Species-Environment Relationships of Mosses in New Zealand Indigenous Forest and Shrubland Ecosystems. Plant Ecology, 212, 353-367. https://doi.org/10.1007/s11258-010-9827-5

[52] Alpert, P. and Oechel, W.C. (1982) Bryophyte Vegetation and Ecology along a Topographic Gradient in Montane Tundra in Alaska. Holarctic Ecology, 5, 99-108.

[53] Slack, N.G. (1994) Can One Tell the Mire Type from the Bryophytes Alone? Journal of the Hattori Botanical Laboratory, 149-159.

[54] Locky, D.A., Bayley, S.E. and Vitt, D.H. (2005) The Vegetational Ecology of Black 
Spruce Swamps, Fens, and Bogs in Southern Boreal Manitoba, Canada. Wetlands, 25, 564-582. https://doi.org/10.1672/0277-5212(2005)025[0564:TVEOBS]2.0.CO;2

[55] Startsev, N., Lieffers, V.J. and Landhäusser, S.M. (2008) Effects of Leaf Litter on the Growth of Boreal Feather Mosses: Implication for Forest Floor Development. Journal of Vegetation Science, 19, 253-260. https://doi.org/10.3170/2008-8-18367

[56] Schmalholz, M. and Granath, G. (2013) Effects of Microhabitat and Growth Form on Bryophyte Mortality Associated with Leaf Litter Burial in a Boreal Spruce Forest. Journal of Vegetation Science, 25, 439-446. https://doi.org/10.1111/jvs.12093

[57] Roy, S. and Singh, J.S. (1994) Consequences of Habitat Heterogeneity for Availability of Nutrients in a Dry Tropical Forest. Journal of Ecology, 82, 503-509. https://doi.org/10.2307/2261259

[58] Marschall, M. and Proctor, M.C.F. (2004) Are Bryophytes Shade Plants? Photosynthetic Light Responses and Proportions of Chlorophyll a, Chlorophyll b and Total Carotenoids. Annals of Botany, 94, 593-603. https://doi.org/10.1093/aob/mch178

[59] Glime, J.M. (2007) Bryophyte Ecology. Volume 1. Physiological Ecology. Michigan Technological University and the International Association of Bryologists, Houghton. http://www.bryoecol.mtu.edu

[60] Økland, R.H. (1994) Patterns of Bryophyte Associations at Different Scales in a Norwegian Boreal Spruce Forest. Journal of Vegetation Science, 5, 127-138. https://doi.org/10.2307/3235646

[61] Olsson, B. and Staaf, H. (1995) Influence of Harvesting Intensity of Logging Residues on Ground Vegetation in Coniferous Forests. Journal of Applied Ecology, 32, 640-654. https://doi.org/10.2307/2404659

[62] Peterson, J.E. (1999) The Effects of Forest Harvest on Bryophyte Recolonization in a Mixed Forest in New Brunswick. MSc Thesis, University of New Brunswick, Fredericton.

[63] Austin, M.P. (1980) Searching for a Model for Use in Vegetation Analysis. Plant Ecology, 42, 11-21. https://doi.org/10.1007/BF00048865

[64] Arp, P.A. (1984) Forest Floor Variability and Factor Analysis: A Case Study. Canadian Journal of Soil Science, 64, 457-461. https://doi.org/10.4141/cjss84-046

[65] Arp, P.A. and Krause, H.H. (1984) The Forest Floor: Lateral Variability as Revealed by Systematic Sampling. Canadian Journal of Soil Science, 64, 423-437. https://doi.org/10.4141/cjss84-043

[66] Betts, M.G., Diamond, A.W., Forbes, G.J., Villard, M.A. and Gunn, J.S. (2006) The Importance of Spatial Autocorrelation, Extent and Resolution in Predicting Forest Bird Occurrence. Ecological Modelling, 191, 197-224.

https://doi.org/10.1016/j.ecolmodel.2005.04.027 
Submit or recommend next manuscript to SCIRP and we will provide best service for you:

Accepting pre-submission inquiries through Email, Facebook, LinkedIn, Twitter, etc. A wide selection of journals (inclusive of 9 subjects, more than 200 journals)

Providing 24-hour high-quality service

User-friendly online submission system

Fair and swift peer-review system

Efficient typesetting and proofreading procedure

Display of the result of downloads and visits, as well as the number of cited articles Maximum dissemination of your research work

Submit your manuscript at: http://papersubmission.scirp.org/

Or contact ajps@scirp.org 